\title{
APLIKASI ANIMASI INTERAKTIF PENCAMPURAN TIGA WARNA PRIMER DAN PENGENALAN BENTUK GEOMETRI PADA PAUD AL-MUSLIMUN
}

\author{
Mayya Nurbayanti Shobary, Dwiza Riana, Rangga Sanjaya \\ Sistem Informasi \\ Universitas BSI Bandung \\ Jalan Sekolah Internasional No. 1-6 Antapani, Bandung 40282 \\ mayya.shobary.@yahoo.com, dwiza@bsi.ac.id, rangga.rsj@bsi.ac.id
}

\begin{abstract}
The development of Interactive animation application mixing three colors and introduction of geometric shapes for early childhood, aims to increase learning tool for parents and teachers to attract the attention of children to learn about colors and shapes using interactive animation application. Application built using the concept of PAUD Al-Muslimun in educating early childhood in knowing the result of mixing three primary colors and geometric shapes. The development of application take an example of how theachers in educating early childhood that began with the introduction of color and shapes, and practice how to mix the primary three colors, by showing interisting picture related to colors and shapes are introduced. Data collection methods used for this study is the direct observation of the teaching and learning activities from the perspective of teachers, children and parents to get an idea of the optimal design of an application built on. The development of Interactive animation application mixing three primary colors and introduction of geometric shapes for early childhood for early childhood through the five steps, analyzing, designing, implemeting, testing, and revision errors or shortfall. In this application there are learning processes knowing the primary color and introduction of geometric shapes with support interactive buttons, interesting picture and audio to enhance the absorption of early childhood to the contents of the material, learning and display concerned and to help parents or teachers role in educating children once more creative .
\end{abstract}

Keywords: Applications, Animation, Interactive, Early Childhood

\begin{abstract}
Abstrak - Pembangunan aplikasi animasi interaktif pencampuran tiga warna primer dan pengenalan bentuk geometri untuk anak usia dini, bertujuan untuk menambah sarana pembelajaran untuk orang tua dan guru dalam menarik perhatian anak untuk belajar mengenal warna dan bentuk dengan menggunakan aplikasi animasi interaktif. Aplikasi yang dibangun menggunakan konsep pembelajaran pada PAUD Al-Muslimun dalam mendidik anak usia dini dalam mengenal hasil pencampuran tiga warna primer dan bentuk geometri. Pengembangan aplikasi mengambil contoh dari cara guru dalam mendidik anak usia dini yang dimulai dengan mengenalkan warna dan bentuk, dan mempraktekkan cara mencampur tiga warna primer, dengan menampilkan gambargambar menarik yang berkaitan dengan warna dan bentuk yang dikenalkan. Metode pengumpulan data yang digunakan untuk penelitian ini adalah dengan observasi secara langsung terhadap kegiatan belajar mengajar dari sudut pandang guru, anak dan orang tua untuk mendapatkan gambaran yang optimal terhadap rancangan aplikasi yang dibangun. Pengembangan aplikasi animasi interaktif pencampuran tiga warna primer dan pengenalan bentuk geometri untuk anak usia dini ini melalui lima langkah, yaitu menganalisis, mendesain, mengimplementasikan, uji coba dan merevisi kekeliruan atau menambah kekurangan. Di dalam aplikasi ini terdapat proses-proses pembelajaran mengenal pencampuran tiga warna primer dan bentuk geometri dengan dukungan tombol interaktif, gambar-gambar yang menarik serta audio yang untuk meningkatkan daya serap anak usia dini terhadap isi materi yang ingin disampaikan, serta dilengkapi dengan permainan untuk mengukur keterampilan dan sejauh mana anak mengenal warna dan bentuk. Penggunaan sarana pembelajaran dengan menggunakan teknologi animasi interaktif ini ditinjau dari aspek isi materi, pembelajaran dan tampilan dinilai dapat menarik perhatian anak usia dini serta membantu peran orang tua atau guru dalam mendidik anak lebih kreatif lagi.
\end{abstract}

Kata Kunci : Aplikasi, Animasi, Interaktif, PAUD 


\section{PENDAHULUAN}

Anak-anak memiliki rasa ingin tahu yang luar biasa dan kemampuan untuk menyerap informasi sangat tinggi. Karena keterbatasan serta kekurangan dari pihak orang tua dan guru sangat mempengaruhi dalam peningkatan kualitas anak usia dini (Lilis Suryani, 2007:5). Berharap proses penyampaian dengan media komputer dan diaplikasikan secara interaktif melalui animasi, informasi kepada anak usia dini dapat berjalan lebih mudah dan bisa bermanfaat bagi dunia pendidikan anak usia dini ke depannya (Aulia dkk, 2012:2). Untuk itu, dalam sebuah sistem pembelajaran diharapkan dapat mengikuti perkembangan teknologi. Seperti halnya menggunakan aplikasi-aplikasi interaktif, baik dalam bentuk game ataupun animasi-animasi yang dinamis dalam upaya mendukung suatu proses pembelajaran yang mudah dimengerti namun tetap menyenangkan bagi anak.

Ada beberapa aplikasi edukasi yang dibuat dengan animasi yang interaktif, namun disana dalam penyampaian materi masih terlalu sederhana dan terkesan monoton. Sebagai contoh beberapa aplikasi yang ada hanya untuk pengenalan dasar dan belum menggunakan database untuk penyimpanan data. Seperti halnya pada PAUD Al-Muslimun, dalam penyampaian materi pada anak didik masih manual, yaitu hanya penjelasan teori dengan menggunakan alat tulis dan alat peraga. Dalam hal ini guru dituntut lebih interaktif, karena untuk membuat anak didik tetap tertarik dengan materi yang disampaikan.

\section{KAJIAN LITERATUR}

Kesadaran akan pentingnya pendidikan anak usia dini, mendapatkan perhatian yang cukup menggembirakan dari berbagai kalangan masyarakat, karena mengetahui arti penting mendidik anak sejak usia dini merupakan pengembangan mental anak yang dilandasi alasan bahwa masa kanakkanak adalah masa keemasan (Suryani,2007:1).

Permainan edukasi kreatif adalah permainan yang dirancang untuk kepentingan pendidikan, dan mempunyai beberapa ciri, agar dapat dengan mudah dipergunakan untuk mencapai tujuan, manfaat dan bermacammacam bentuk dan modelnya (Sugiharto,2012:3).

Pemberian materi dengan menggunakan animasi, membuat $90 \%$ anak didik setuju dengan model pembelajaran demikian, karena hal tersebut memudahkan anak didik paham dengan materi yang disampaikan (Umar,2011:35).

Warna terdiri atas warna primer dan warna sekunder. Warna primer meliputi warna merah, kuning, dan biru. Warna sekunder dibentuk dengan mencampur dua atau lebih warna primer (Suyanto,2012:8).

Game tidak hanya dimanfaatkan untuk hiburan saja, tetapi juga sebagai media edukasi. manusia memiliki sifat dasar lebih cepat mempelajari segala sesuatu secara visual-verbal, sehingga game juga baik jika dilibatkan dalam proses pendidikan. (Rachman,2012:4)

\section{METODE PENELITIAN}

Metode pengumpulan data diperoleh secara langsung dari objek penelitian. Caracara yang mendukung untuk mendapatkan data primer adalah sebagai berikut :

1. Observasi

Melakukan pengamatan secara langsung terhadap proses belajar mengajar anak usia dini di PAUD Al-Muslimun.

2. Wawancara

Melakukan tanya jawab langsung dengan berbagai pertanyaan yang sudah disusun sebelumnya atau dikembangan dari pertanyaan yang ada mengenai proses pembelajaran dan kendala-kendala yang dihadapai anak saat belajar di PAUD AlMuslimun.

3. Studi pustaka

Mempelajari dan meneliti dari berbagai literatur pendidikan anak usia dini, animasi edukatif, teknologi multimedia serta jurnal-jurnal penelitian yang sudah dilakukan sebelumnya.

\section{PEMBAHASAN}

Yayasan Pendidikan Nurul Wasiat merupakan yayasan yang bergerak di bidang pendidikan yang didirikan pada tanggal 07 Juli 2007. Yayasan Pendidikan Nurul Wasiat mendirikan beberapa lembaga pendidikan yang diantaranya adalah RA / TK, PAUD Islam AlMuslimun yang beralamat di Kp. Panyadaan RT 02 RW 14 Desa Jambudipa Kecamatan Cisarua Kabupaten Bandung Barat, dengan nomor ijin operasional 420.1.5076.964/DISDIKPORA/2010 yang dikeluarkan oleh Dinas Pendidikan Kabupaten Bandung Barat. 


\section{Analisis Kebutuhan}

Sebelum proses perencanaan membangun sebuah program, perlu dilakukan suatu analisis yang tepat tentang apa saja yang dibutuhkan hingga tercapainya sebuah aplikasi yang diharapkan. Pada bagian analisis kebutuhan, akan dibahas mengenai identifikasi dan analisa kebutuhan pemakai, analisa kebutuhan sistem, serta perangkat lunak untuk mendesain dan membangun sistem.

\section{Identifikasi dan Analisa Kebutuhan Pemakai}

Agar aplikasi yang dikembangkan sesuai dengan kebutuhan pengguna, maka tahapan ini sangat diperlukan untuk mengetahui apa saja yang user butuhkan.

Sasaran dari sistem yang akan dikembangkan adalah anak-anak umur 2 tahun sampai 6 tahun. Sistem yang akan dikembangkan berupa sebuah aplikasi animasi interaktif pencampuran tiga warna primer dan pengenalan bentuk geometri. Ada beberapa kegiatan yang dilakukan pada tahap ini antara lain seperti yang dijelaskan pada penjelasan berikut:

1. Pengambilan data dengan melakukan pengamatan langsung (observation) yang bertujuan untuk mengetahui kebutuhan dari pemakai (user) sebagai responden objek penelitian. Responden dari objek penelitian ini adalah anakanak usia 2 sampai 6 tahun pada PAUD Al-Muslimun. Melakukan pengamatan dan menganalisa pada sistem yang saat ini digunakan. Fokus pengamatan adalah tentang proses pembelajaran mencampur tiga warna primer, dan mengenal bentuk geometri untuk anak usia 2-6 tahun. Dari hasil pengamatan yang dilakukan di PAUD Al-Muslimun, terlihat bahwa sistem pengajaran pengenalan warna, bentuk serta pencampuran warna dilakukan dengan menggunakan alat peraga seperti : cat air berwarna primer untuk materi pencampuran tiga warna primer, dan menggambarkan bentuk dengan menggunakan whiteboard untuk mengenalkan bentuk geometri kepada anak didik.

2. Melakukan wawancara (interview) pada responden sebagai pemakai yang menjadi objek penelitian. Dari wawancara yang dilakukan diperoleh hasil bahwa :

a. Proses pembelajaran pencampuran warna dimulai dari mengenalkan tiga warna primer, yaitu : merah, kuning, biru. Dari sana guru memperagakan dengan menggunakan cat air berwarna, dari campuran 2 warna primer akan didapatkan 3 warna sekunder yaitu: jingga, ungu, dan hijau. Dan dari campuran ketiga warna primer tersebut didapat warna cokelat.

b. Proses pembelajaran pengenalan bentuk geometri, guru menggambar serta menjelaskan bentuk-bentuk geometri dimulai dari bentuk lingkaran, bujur sangkar, persegi panjang, segitiga, segilima, belah ketupat, dan jajaran genjang. Meski masih banyak lagi bentuk geometri yang lainnya, namun untuk materi dasar pengenalan bentuk geometri, guru hanya menjelaskan tujuh bentuk geometri saja, karena ketujuh bentuk tersebut sering dijumpai di lingkungan sekitar.

3. Melakukan analisa terhadap data yang ada, dari analisa terhadap dokumen hasil observasi dan wawancara kepada responden diketahui bahwa:

a. Proses pembelajaran mencampur warna dan pengenalan bentuk geometri pada PAUD Al-Muslimun masih menggunakan teknik pengajaran yang sederhana, dimana guru memperagakan cara mencampurkan warna serta hasil warna yang didapat, tanpa mengajak anak didik terlibat langsung dalam proses mencampur tiga warna primer tersebut. Dan dalam materi pengenalan bentuk geometri, guru hanya menjelaskan dengan metode linier, sehingga membuat anak didik cepat bosan dan lupa dengan bentuk yang dijelaskan sebelumnnya.

b. Anak didik tidak mampu mengembangkan lebih kreatif lagi mengenai pencampuran warna serta pengenalan bentuk geometri.

c. Perlu menggunakan animasi interaktif dalam penyampaian kedua materi di atas untuk meningkatkan daya tarik anak pada kedua materi tersebut.

d. Waktu belajar yang sangat terbatas sehingga mengakibatkan proses belajar pencampuran tiga warna primer dan pengenalan bentuk geometri kurang maksimal.

Metode pembelajaran untuk anak usia dini dengan menggunakanaplikasi animasi interaktif, diharapkan dapat membantu anak dalam aktifitas belajar yang komunikatif dan menarik. Dengan penggunaan gambar, warnawarna, serta suara yang dapat merangsang anak untuk lebih aktif. 
Materi pencampuran tiga warna primer dan pengenalan bentuk geometri, perlu disampaikan untuk anak usia dini, untuk mendukung dalam mengembangkan kreatifitas seni serta imajinasi dari anak itu sendiri.

\section{Analisa Kebutuhan Sistem}

Untuk membangun sebuah aplikasi animasi interaktif sebagai media pembelajaran yang menarik, diperlukan konsep animasi dan perencanaan perancangan sistem yang akan dibangun. Untuk itu diperlukan dukungan sistem perangkat komputer yang memadai baik dari hardware maupun software. Dalam pemilihan hardware dan software perlu dipertimbangkan beberapa hal, antara lain sebagai berikut :

1. Hardware dan software yang digunakan harus mempertimbangkan sistem yang saat ini digunakan ataupun yang akan datang.

2. Hardware dan software yang digunakan harus disesuaikan dengan perkembangan teknologi komputer yang sedang berkembang saat ini.

3. Hardware dan software yang digunakan diharapkan dapat menekan biaya operasional namun tetap optimal untuk setiap informasi yang didapat.

\section{Perangkat Untuk Mendesain dan Membangun Sistem \\ Pada bagian ini akan dibahas mengenai hardware dan software untuk \\ mendesain dan membangun sistem dengan spesifikasi sebagai berikut :}

Tabel 1

\section{Spesifikasi Hardware dan Software}

\begin{tabular}{c|c}
\hline Kebutuhan & Spesifikasi \\
\hline Hardware & \\
\hline Processor & Intel Core i3 2310M \\
\hline Memory & DDR3 2 GB \\
\hline HDD & Resolusi GB 1366 x 768, \\
\hline Display & 1 Unit \\
\hline Mouse & Microsoft Windows 7 \\
\hline Software & Ultimate \\
\hline Sistem operasi & Adobe Flash CS3 \\
\hline IDE & Soundbooth, coreldraw 12 \\
\hline Tools &
\end{tabular}

\section{Perancangan Animasi Interaktif}

Pada tahap pembuatan aplikasi ini akan dibahas mengenai perancangan storyboard dan perancangan user interface.

Dalam merancang animasi ini harus berpedoman pada karakterstik dan unsur-unsur pembuatan sebagai berikut :

1. Format

Format animasi pembelajaran ini memilki empat tahapan diantaranya mencampur warna, pengenalan, games dan profil. Pada menu mencampur warna, pengguna diberikan gambaran empat tombol hasil pencampuran warna, yang apabila di pilih salah satu dari tombol tersebut akan menampilkan animasi mencampur warna sehingga terbentuk warna yang sesuai dengan tombol yang dipilih. Pada menu pengenalan, pengguna diberikan pilihan sub menu pengenalan warna dan pengenalan bentuk geometri, yang apabila dipilih salah satu dari kedua sub menu tersebut akan menampilkan animasi tentang pengenalan warna dan pengenalan bentuk geometri. Pada menu games pengguna diberi tiga sub menu pilihan untuk game mewarnai, game mencocokkan, dan game quiz. Untuk game mewarnai pengguna akan diberikan beberapa pilihan gambar untuk diwarnai sesuai keinginan pengguna, disana sudah disiapkan palet warna yang bisa dipilih untuk mewarnai gambar yang masih polos. Untuk game mencocokkan pengguna diharuskan mencocokkan warna yang sesuai dengan disediakan enam kotak warna yang berbeda, apabila sesuai akan mendapat pilihan terus berlanjut ke-level berikutnya atau keluar dari permainan. Untuk game quiz pengguna diberikan 10 soal, apabila jawaban betul akan lanjut ke soal berikutnya, tapi bila jawaban salah akan kembali ke soal pertama. Pada menu profil pengguna akan diberikan informasi mengenai tujuan dibuatnya aplikasi dan informasi mengenai pembuat aplikasi.

\section{Rules}

Pada aplikasi ini pengguna diharuskan mempelajari animasi pencampuran warna dan pengenalan warna serta pengenalan bentuk geometri, untuk membantu dalam menyelesaikan games yang disediakan.

3. Policy

Ketika pengguna menjawab betul pertanyaan, akan berlanjut ke soal berikutnya, dan apabila tidak akan kembali ke soal pertama.

\section{Scenario}

Pertama kali pengguna diberi menu pilihan untuk masuk kedalam menu utama. Di 
dalam menu utama terdapat empat menu pilihan, namun disarankan pengguna untuk mempelajari menu mencampur warna dan pengenalan warna serta pengenalan bentuk geometri sebelum bermain dan memilih salah satu game. Pengguna bisa memilih salah satu sub menu game mewarnai, dimana pengguna diberi kebebasan utnuk memilih gambar dan mewarnai sesuai dengan palet yang disediakan. Pengguna memilih sub menu game mencocokkan, dimana pengguna diminta untuk mencocokkan warna yang ada ke dalam target yang disediakan, apabila warna sesuai akan lanjut ke level berikutnya. Pada sub menu game quiz, pengguna diminta menjawab 10 soal. Pada sub menu game mencocokkan pengguna diminta mencocokkan objek yang disediakan dengan target yang ada. Pada menu profil, pengguna diberi pilihan menu aplikasi dan menu pembuat . Pertama kali pengguna diberi pilihan untuk mempelajari materi mencampur warna, pengenalan warna, dan pengenalan bentuk geometri sebelum memilih menu games. Setelah itu pengguna akan diminta untuk menjawab soal quiz atau yang dibuat dengan 10 pertanyaan. Selain itu pengguna dapat bermain game mewarnai, dimana pengguna akan diminta untuk mewarnai gambar yang sudah ada dengan menggunakan palet warna yang disediakan. Untuk game mencocokkan, pengguna diminta mencocokkan beberapa warna yang ada untuk disesuaikan dengan target. Apabila sesuai akan lanjut ke tingkatan berikutnya. Semua proses mulai dari pilihan mencampur warna, pengenalan, games dan profil yang disertai gambar dan suara musik agar anak dapat dengan mudah mengenal objek yang ditampilkan.

5. Event

Pada permainan ini tantangan yang diberikan adalah pemain harus menjawab 10 soal. Soal yang diberikan berupa beberapa bentuk dan warna yang materinya sudah ada pada menu mencampur warna, dan pengenalan.

6. Decision

Keputusan yang dapat dibuat pengguna dalam hal ini adalah misalnya dalam game mewarnai, dapat memilih gambar sesuai keinginan untuk diwarnai. Dan dalam permainan quiz pengguna dalam hal ini diberi pilihan untuk menjawab soal yang tepat agar dapat melanjutkan ke-level berikutnya. Selain itu pada permainan mencocokkan, pemain dapat membuat keputusan untuk meletakkan warna yang sesuai pada warna target yang tepat.

7. Levels

Pada game mencocokkan, diberikan lima tingkatan dalam menyelesaikan permainan, dimana dalam setiap tingkatan tersebut akan menambah jumlah target yang harus dicocokkan warnanya. Serta pada game quiz terdapat 10 tingkatan apabila menyelesaikan seluruh jawaban dengan benar.

8. Skor

Dalam hal ini, game quiz diberikan skor berupa nilai 100-1000. Jika pengguna menjawab betul akan lanjut ke soal berikutnya dan skor bertambah, apabila salah akan kembali ke soal pertama dengan skor awal 0.

9. Indikator

Indikator yang digunakan dalam game quiz, dan game mencocokkan adalah warna dan bentuk. Seperti warna primer, warna sekunder, bentuk kotak, dan gabungan dari keduanya.

10. Symbol

Sebagai penunjuk ke state berikutnya atau ke state sebelumnya digunakan tombol home. Selain itu juga terdapat tomboltombol pada menu yang berupa gambar yang digunakan untuk menuju ke menumenu yang disediakan.

Dari kriteria-kriteria tersebut, maka dibentuklah perancangan sistem yang akan dibagi menjadi dua perancangan, yaitu perancangan storyboard, perancangan user interface.

\section{Perancangan Storyboard}

Perancangan storyboard ini berisi pembahasan mengenai alur cerita dari

Aplikasi yang dibangun, akan disampaikan dengan menggunakan tulisan dan gambar.

\section{Perancangan State Transition Diagram}

Merupakan diagram yang

memodelkan tingkah laku (bihavior) sistem berdasarkan pada definisi satu bagian dari keadaan sistem. State Transition Diagram sering dipakai untuk menggambarkan kinerja sistem.

Komponen state transition diagram dibagi menjadi 4 yaitu : State (kondisi dari suatu sistem), State Change (tanda panah), kondisi dan aksi. Untuk menjelaskan alur dari aplikasi yang dibuat, penulis menggambarkan dengan menggunakan state transition diagram. 


\section{Perancangan User Interface}

Rancangan user interface dari aplikasi yang dibuat berdasarkan storyboard yang terdiri dari rancangan menu home, menu utama, menu mencampurkan warna, menu pengenalan, menu games, menu profil, sub menu pengenalan warna, sub menu pengenalan bentuk, sub menu game mewarnai, sub menu game mencocokkan, dan sub menu game quiz. Berikut akan digambarkan perancangan user interface dari aplikasi animasi interaktif pencampuran tiga warna primer dan pengenalan bentuk geometri :

\section{1. $\quad$ Menu Opening}

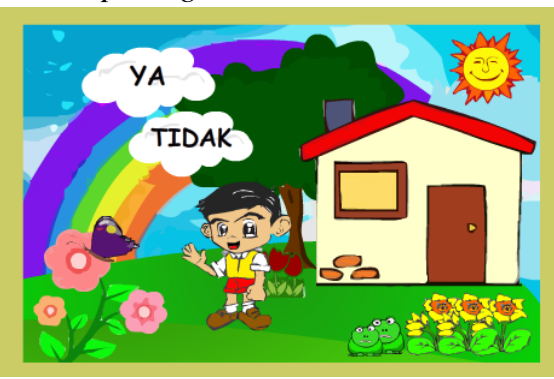

Gambar 1

\section{Tampilan Menu Opening}

Gambar di atas adalah tampilan menu opening pada program yang terdiri dari pilihan tombol ya dan tidak.

\section{Menu Utama}

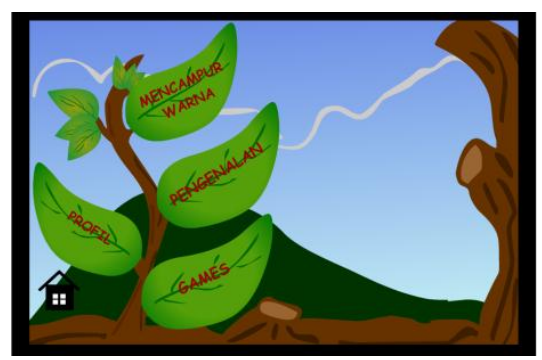

Gambar 2

Tampilan Menu Utama

Gambar di atas adalah tampilan menu utama pada program yang terdiri dari pilihan tombol mencampur warna, pengenalan, games, profil dan exit.

3. Menu Mencampur Warna

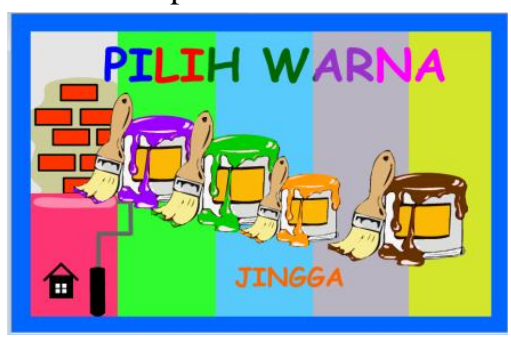

Gambar 3

Menu Mencampur Warna
4. Menu Pengenalan Warna dan Mengenal Bentuk Gemetri

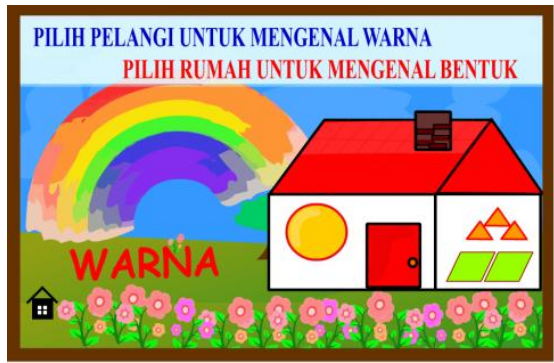

Gambar 4

Menu Pengenalan Warna dan Mengenal Bentuk Gemetri

5. Menu Games

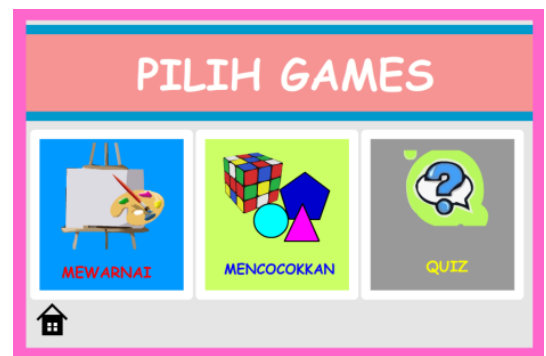

Gambar 5

Tampilan Menu Games

Gambar di atas adalah tampilan menu games, terdapat 3 tombol pilihan games, dan tombol exit.

\section{Menu Profil}

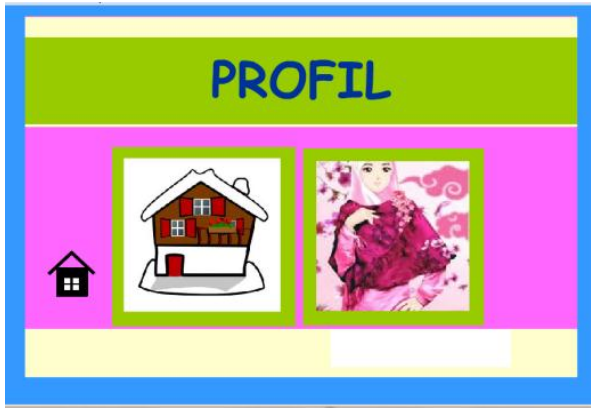

\section{Gambar 6 Tampilan Menu Profil}

\section{Pengujian Sistem}

Langkah terakhir sebelum perangkat lunak diimplementasikan adalah melakukan pengujian (testing) terhadap sistem/perangkat lunak yang dibuat. Pada bagian pengujian sistem akan dibahas mengenai pengujian 
perangkat lunak dengan metode white-box dan black-box testing

\section{Pengujian White Box}

Dengan menggunakan metode pengujian white box, perekayasaan sistem dapat melakukan test case yang dapat memberikan jaminan bahwa semua jalur independen pada suatu modul telah digunakan paling tidak satu kali, Menggunakan semua keputusan logis pada sisi true dan false. Mengeksekusi semua loop (perulangan) pada batasan mereka dan pada batas operasional mereka.

\section{Pengujian Black box}

Pengujian black box dilakukan untuk memastikan bahwa suatu masukan akan menjalankan proses yang tepat dan menghasilkan output sesuai dengan rancangan.
Salah satu instrument pengumpul data dalam penelitian adalah kuesioner, atau disebut juga daftar pertanyaan yang terstruktur. Kuesioner ini biasanya berkaitan erat dengan masalah penelitian, atau juga hipotesis penelitian yang dirumuskan. Disebut juga dengan istilah pedoman wawancara (interview schedule), dengan istilah generiknya yaitu kuesioner. Kuesioner adalah pertanyaan tertulis yang diberikan kepada responden untuk menjawab. Sebelumnya harus dipastikan kebenaran atas responden yang diteliti berdasarkan kriteria respondennya. Tujuan kuesioner adalah untuk memberikan tinjauan tentang ekspresi metafora dalam berbagai macam bahasa di dunia.

Untuk mendapatkan informasi mengenai hasil rancangan aplikasi yang dibangun, penulis melakukan penelitian terhadap 20 orang responden yang terdiri dari guru PAUD dan orang tua yang memiliki anak usia dini.

\section{Hasil Pengolahan Data Kuesioner}

Berikut dari hasil pengolahan data kuesioner yang didapat.

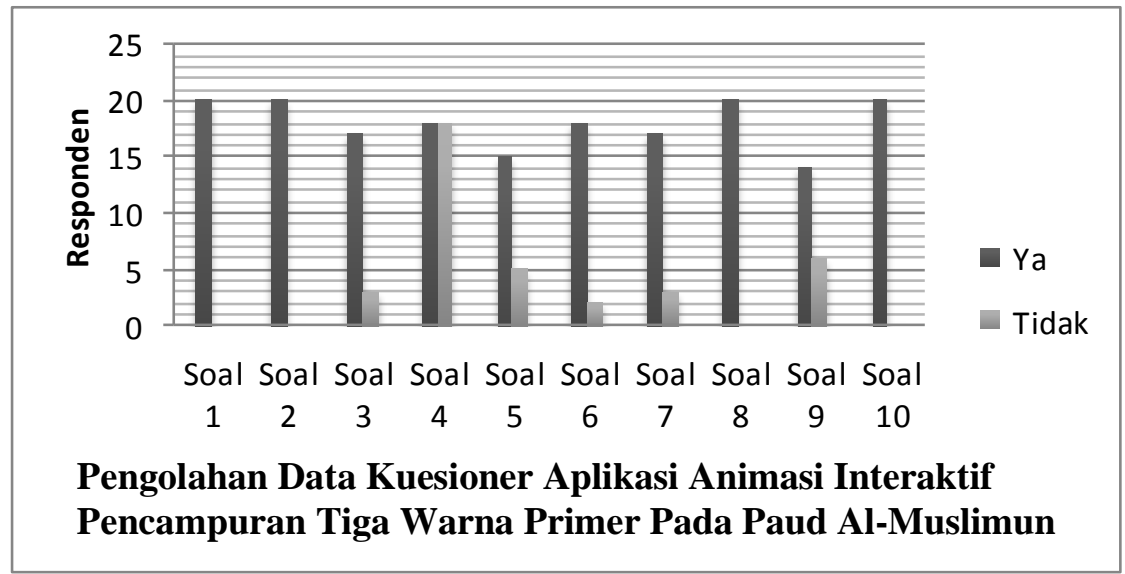

Gambar 7

Grafik Pengolahan data Kuesioner

Dari hasil persentase Pada di atas, didapatkan $89,5 \%$ responden yang memilih ya dan $10,5 \%$ memilih menjawab tidak.

Tabel 2

Pengolahan Data Kuesioner

\begin{tabular}{cccccccccccc}
\hline & $\begin{array}{c}\text { Soal } \\
1\end{array}$ & $\begin{array}{c}\text { Soal } \\
2\end{array}$ & $\begin{array}{c}\text { Soal } \\
3\end{array}$ & $\begin{array}{c}\text { Soal } \\
4\end{array}$ & $\begin{array}{c}\text { Soal } \\
5\end{array}$ & $\begin{array}{c}\text { Soal } \\
6\end{array}$ & $\begin{array}{c}\text { Soal } \\
7\end{array}$ & $\begin{array}{c}\text { Soal } \\
8\end{array}$ & $\begin{array}{c}\text { Soal } \\
9\end{array}$ & $\begin{array}{c}\text { Soal } \\
10\end{array}$ & Jumlah \\
\hline Ya & $\mathbf{2 0}$ & $\mathbf{2 0}$ & $\mathbf{1 7}$ & $\mathbf{1 8}$ & $\mathbf{1 5}$ & $\mathbf{1 8}$ & $\mathbf{1 7}$ & $\mathbf{2 0}$ & $\mathbf{1 4}$ & $\mathbf{2 0}$ & 179 \\
\hline Tidak & 0 & 0 & 3 & 2 & 5 & 2 & 3 & 0 & 6 & 0 & 21 \\
\hline
\end{tabular}

Total Soal 200 
Dilihat dari Tabel. 2. Didapat kesimpulan, bahwa aplikasi yang dibangun sudah cukup membantu dalam penyampaian materi pencampuran warna dan pengenalan bentuk geometri, serta dari tampilan cukup memuaskan user. Dapat dilihat dari segi cara mengoperasikan yang mudah dan tidak terlalu banyak aturan, karena setiap scene dipandu dengan sound yang membantu anak mempelajari materi yang ada pada aplikasi tersebut dengan mandiri.

\section{PENUTUP}

\section{Kesimpulan}

Pembelajaran anak usia dini dalam mencampurkan tiga warna primer dan pengenalan bentuk geometri dianggap sangat diperlukan untuk disampaikan sejak usia dini. Karena menunjang untuk pembelajaran seni rupa dan berbagai pengenalan warna serta bentuk yang sering dijumpai anak sehari-hari. Namun pemberian materi tersebut kepada anak usia dini dinilai kurang tepat, karena anak usia dini seharusnya lebih diarahkan untuk mengembangkan kemampuan bereksplorasi.

Pembuatan aplikasi animasi interaktif pencampuran tiga warna premier dan pengenalan bentuk geometri menjadi alternatif yang sangat menarik, melihat cara penyampaian materi dan tenaga pengajar yang masih terbatas menjadi hambatan untuk merangsang daya pikir kreatifitas anak untuk mengembangkan materi yang ada. Aplikasi animasi interaktif memberikan kemudahan guru dan orang tua dalam proses pembelajaran materi pencampuran tiga warna primer dan pengenalan bentuk geometri, dengan tidak adanya unsur paksaan karena menarik minat anak untuk belajar lebih mandiri.

Aplikasi yang dibangun dapat menjadi alternatif media pembelajaran untuk anak usia dini yang bisa dipelajari di sekolah ataupun di rumah. Penyajian materi dengan animasi yang didukung dengan gabungan suara, gambar serta background yang menarik perhatian anak, tentunya akan menjadi solusi terbaik

\section{REFERENSI}

Lilis. 2007. Analisis Pendidikan Anak Usia Dini Dalam Masyarakat Indonesia. Jakarta. UHAMKA
Juknis. 2011. Petunjuk Teknis Pelaksanaan PAUD. Jakarta : Kementrian Pendidikan Nasional

Santoso. 2012. Optimalisasi Tumbuh Kembang Anak Usia Dini Menuju Anak yang Sehat dan Cerdas Melalui Permainan . Jakarta : Universitas Negeri Jakarta

Anonim. Pandangan para ahli tentang pendidikan anak usia dini. http://sinarmentari4u.blogspot.co $\mathrm{m}$, diakses tanggal 01 November 2012.

Anonim. Metode belajar bagi anak usia dini. http://peperonity.com, diakses tanggal 01 November 2012. 
Jurnal Informatika. Vol. I No. 2 September 2014 